\title{
Absence of Gliosis in the Brains of Epileptic Fowl
}

\author{
D.G. Munoz, B. McNab, D.H. George and D. Johnson
}

\begin{abstract}
Chickens homozygous for the epi gene (epileptics) suffer from spontaneous seizures throughout their life, whereas heterozygous (carriers) are phenotypically normal. Seizures can also be evoked in epileptics by photic stimulation. In addition, epileptic chickens' brains are $25 \%$ heavier than those of carriers. We have investigated whether hyperplasia or hypertrophy of astrocytes or increased numbers of astrocytic processes are involved in the development of seizures and the megalencephaly in this model by quantitative comparison of sections immunocytochemically stained for glial fibrillary acidic protein (GFAP). No statistically significant differences between epileptics and controls were found in any of seven areas selected for comparison. In this model gliosis is not involved in the development of epilepsy, nor does it result from repeated seizures.

RÉSUMÉ: Absence de gliose dans le cerveau des volailles épileptiques Les poulets qui sont homozygotes pour le gène épi (épileptiques) présentent des convulsions spontanées pendant toute leur vie, alors que les hétérozygotes (porteurs) sont phénotypiquement normaux. Les crises convulsives peuvent également être provoquées par stimulation photique chez les poulets épileptiques. De plus, le cerveau des poulets épileptiques est de $25 \%$ plus lourd que celui des porteurs. Nous avons étudié la possibilité que l'hyperplasie, l'hypertrophie des astrocytes ou une augmentation du nombre des prolongements astrocytaires soit responsable de l'apparition des crises convulsives et de la mégaencéphalie dans ce modèle animal, en comparant de façon quantitative des coupes colorées pour la protéine fibrillaire acide de la glie par une technique immuno-cytochimique. Nous n'avons pas constaté de différence statistiquement significative entre les épileptiques et les contrôles dans les sept régions choisies pour fins de comparaisons. Chez ce modèle animal, le gliose n'est pas impliquée dans le développement de l'épilepsie et n'est pas le résultat de crises convulsives répétées.
\end{abstract}

Can. J. Neurol. Sci. 1988; 15: 409-412

The primary generalized epilepsies are the least understood of the epilepsies. While it is clear that genetic factors play an important role in the development of many of these disorders, 1,2 the structural abnormalities underlying the predisposition to epilepsy are, by definition, not immediately apparent, and have not been fully characterized in the human. Animal models of primary generalized epilepsy provide an opportunity to analyze the cellular or supracellular disorders in the structure of the brain leading to and resulting from seizures. Important advances in this regard have been the demonstration in the seizure sensitive gerbil of abnormalities in the pattern of dendritic spines in $\mathrm{CA} 3$ cells and mossy tufts contacting them, ${ }^{3}$ and of an increased number of inhibitory GABAergic neurons in the dentate gyrus. ${ }^{4}$

An autosomal recessive mutation in domestic fowl, first reported by Crawford ${ }^{5}$ at the University of Saskatchewan, is associated with high seizure susceptibility throughout life. Homozygous (epi, epi) chickens, designated epileptics, suffer from spontaneous convulsions from hatching and throughout their life span. In addition, seizures can be induced by stress such as muscular exertion or combined auditory and optic stimulation, and most readily by intermittent photic stimulation at 14 flashes per second. ${ }^{6}$ Heterozygous (Epi, epi) chickens, desig- nated carriers, do not experience spontaneous or induced convulsions. Epileptic chickens show markedly abnormal interictal EEG recordings. ${ }^{6}$ Seizures induced by stroboscopic stimulation respond to treatment with phenobarbital, phenytoin, valproic acid, trimethadione and benzodiazepines, but are unaffected by ethosuximide. ${ }^{7}$ In addition, seizures can be induced in newly hatched chicks, but not in adult birds, by elevating their body temperature. These seizures precede and differ in motor seizure pattern from a second clonic-tonic seizure that can be evoked by hyperthermia in both epileptic and carrier chicks. ${ }^{8}$

In addition to epilepsy, homozygosity for the epi gene results in megalencephaly, brains of epileptic chicken being $25 \%$ heavier (fresh weight) than brains of carrier chickens. This difference, present at hatching, is not accompanied by increased body weight. ${ }^{9}$

The goal of the present study was to determine whether the brains of epileptic chickens show gliosis, as determined by immunocytochemical staining for glial fibrillary acidic protein (GFAP), a recognized astrocytic marker in avian as well as mammalian brain. In birds, as in mammals, expression of GFAP is restricted to fibrillary astrocytes under normal conditions, but is maximally developed in reactive astrocytes that appear in response to injury. ${ }^{10} \mathrm{~A}$ number of epilepsy models induced in 
previously normal animals are accompanied by reactive gliosis at the site of the focus. These models include alumina cream in monkeys and cats, cobalt in rats, and iron in rats (see Ribak, 1986 for references). ${ }^{4}$ It has been postulated that such reactive gliosis contributes to the development of seizures through altered glial-neuronal metabolic relationships. ${ }^{.1,12,13,14}$ On the other hand the patterned gliosis observed in the hippocampus following amygdalar or systemic injections of convulsants such as kainic acid, folic acid, bicuculline or cholinergic agonists appears to be the result of seizures, since both seizures and distant brain damage can be blocked by diazepam. This pattern of damage, hypothesized to be due to the excessive release of excitatory aminoacids, is not restricted to the hippocampus, but has been observed in specific thalamic nuclei that receive glutaminergic innervation from cortical neurons involved in seizures following supradural application of various convulsants. ${ }^{15}$ The characteristic mesial temporal sclerosis in human temporal lobe epilepsy is considered to result from similar mechanisms. ${ }^{16}$ The role of such scar tissue in the generation of seizures is evident from the improvement that follows its surgical resection. ${ }^{17}$

Our study was intended to test the hypothesis that an excessive production of astrocytes underlies both the megalencephaly and the predisposition to seizures of epileptic fowl. In the presence of gliosis, studies in newly hatched chickens would have been necessary to test whether excess astrocytes are generated in response to seizures.

\section{Materials and Methods}

The chickens used in these studies were drawn from the epileptic mutant population maintained at the University of Saskatchewan by mating homozygous recessive birds (epi, epi) with heterozygous birds (Epi, epi). The phenotype of the offspring was determined on the basis of their response to intermittent photic stimulation. Ten adult females, 5 epileptic and 5 carriers, were perfused through the left cardiac ventricle with 0.1 $\mathrm{M}$ phosphate buffered saline followed by $4 \%$ paraformaldehyde in $0.1 \mathrm{M}$ phosphate buffer. After removal from the cranium, the brains were postfixed by immersion in the same fixative for 24 hours, washed in $0.1 \mathrm{M}$ phosphate buffer, serially sectioned in the coronal plane, and embedded in paraffin. Ten $\mu \mathrm{m}$ thick histological sections taken every $100 \mu \mathrm{m}$ through the blocks were stained with luxol fast blue and cresyl violet to identify the areas of interest by comparison with the atlases of Jungherr ${ }^{20}$ and van Tienhoven and Juhasz. ${ }^{21}$ Adjacent sections were immunocytochemically stained for GFAP by the avidin-biotin method using Vectastin kits (Vector), as previously described. ${ }^{22}$ The immunoreactivity of the primary anti-GFAP antiserum, purchased from DAKO, and used at a dilution of 1:200, has been reported. ${ }^{22}$

The following regions were selected for study: hippocampus dorsalis, nucleus rotundus, stratum griseum et fibrosum superficiale of the optic tectum, stratum album centrale of the optic tectum, cerebellar granule cell layer, cerebellar white matter and paleostriatum. The areas were chosen because they could be accurately identified, and as to include;

i) A region - hippocampus dorsalis - homologous to the mammalian hippocampus, known to be gliotic in some cases of human epilepsy, and to show neuronal loss in an animal model of primary generalized epilepsy, the mongolian gerbil. 18

ii) Regions - nucleus rotundus and optic tectum - involved in the visual pathway, ${ }^{19}$ because of the ease with which seizure can be induced by stimulation of this system.

iii) Other general regions - the cerebellum and paleostriatum - as control for the specificity of the changes.

Slides were examined under a magnification of $320 \mathrm{x}$ and, using an ocular grid, GFAP positive perikarya and processes were counted in 6 randomly chosen fields, each $0.0625 \mathrm{~mm} 2$. No fiber counts were made in the stratum album centrale, cerebellar granular layer, and cerebellar white matter, due to the high density and overlapping pattern of fibers in these regions, that make accurate counting impossible. Comparison of the number of cell bodies and fibers between epileptics and carriers for each region was by means of the non-parametric KruskalWallis test. Systematic counts were done by one of us (BM) and randomly chosen slides checked by a second individual (DGM). Differences between counts were less than $10 \%$. Although slides were coded, the difference in size of the brains of epileptic chickens compared to carriers prevented effective blinding.
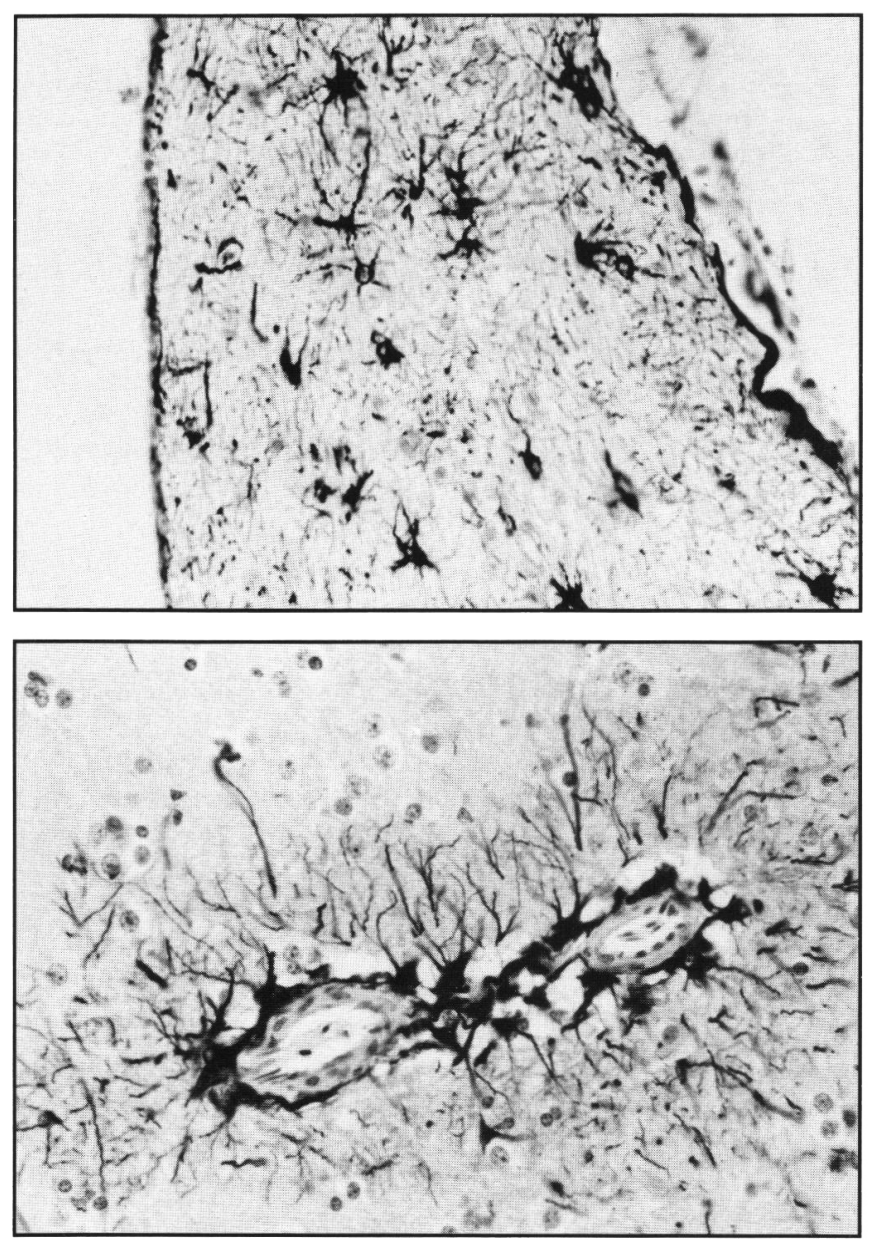

Figure 1 - Patterns of distribution of GFAP-positive cell bodies.

A) Hippocampus dorsalis. Astrocytic cell bodies are scattered in the parenchyma, and both radially and tangentially oriented processes are seen subpially (to the right) and subependymally (to the left). $\times 290$

B) Accumulation of GFAP-positive perikaryon and processes around blood vessels in the hyperstriatum. $\times 290$ 

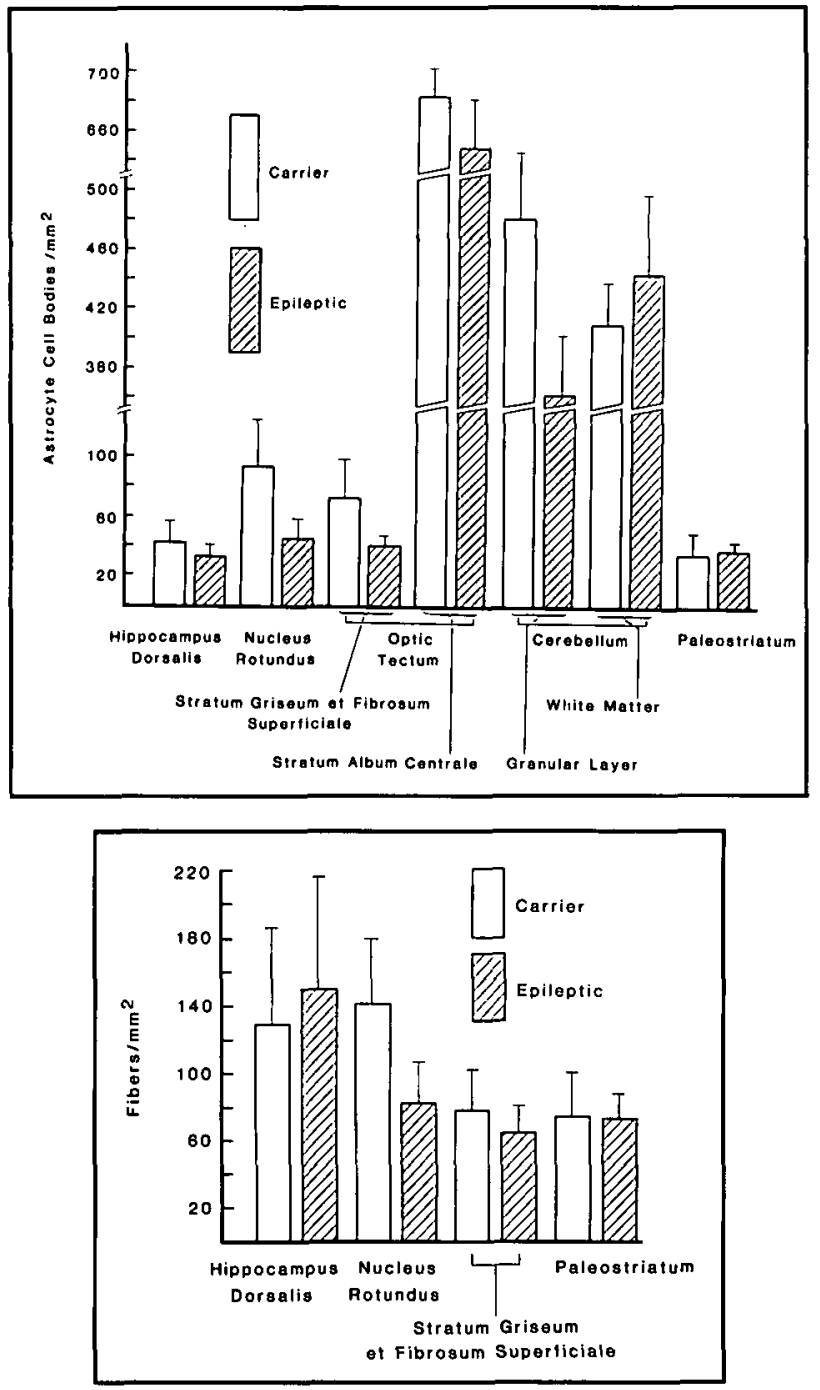

Figure $2-A)$ Density of astrocyte cell bodies in several regions in carriers and epileptics. Bars represent standard error of the mean B) Density of astrocytic processes (fibers) in several regions in carriers and epileptics. Bars represent standard error of the mean.

\section{Results}

Apart from global increase in brain size, no abnormalities were detected on gross and routine histological examination of the brain of epileptic chicken. GFAP immunoreactivity was distributed in astrocytic perikarya from which processes radiated in a stellate fashion, as well as in fibers whose connection to a cell body was not apparent in the plane of section (Figure 1). Both cell bodies and fibers were abundant in the subpial and subependymal regions, around blood vessels, and in certain anatomical structures such as the stratum album centrale of the optic tectum, and the granular layer of the cerebellar cortex. Visual scanning of the GFAP-stained slides did not reveal any obvious differences between carriers and epileptics. Quantitative studies were undertaken in the seven selected regions; the average density of GFAP positive cell bodies and fibers for each region counted is presented in Figure 2. No observed differences between epileptics and carriers approached the 0.05 level of significance in the non-parametric KruskalWallis test.

\section{Discussion}

We have shown that the brain of epileptic fowl does not contain an increased density of cell bodies of fibrous astrocytes, and that those astrocytes present do not send forth an excess of GFAP-positive processes. The implications are threefold: i) the megalencephaly of epileptic chickens is not dependent on an increased density of fibrous astrocytes. However, it is possible that the total number of fibrous astrocytes is increased along with other cell types in the brains of epileptic fowl. ii) Gliosis cannot be involved in the development of epilepsy in this model since it is not present in adult fowl. Once established by whatever mechanism, gliosis is permanent. iii) Seizure activity in epileptic fowl does not result in gliosis. This statement is only applicable to seizures occurring spontaneously. It has not been proven that a high frequency of induced seizures does not produce gliosis.

Although a lack of activated astrocytes was recognized qualitatively in the kindling phenomenon, 12 we are not aware of previous reports addressing the issue of gliosis in a genetically determined epilepsy. Paul et $\mathrm{al}^{3}$ stated that the hippocampus of seizure sensitive gerbils were "not scarred" and Ribak ${ }^{4}$ cites a personal communication of $R$. Naquet indicating the lack of scarring in grand mal epilepsies in baboons. The results of our quantitive study in epileptic fowl agree with the impressions obtained in the two other models of genetically determined epilepsy in animals mentioned above. In none of them does gliosis appear to be either an antecedent or a consequence of generalized seizures. This is in contrast with the consistent presence of gliosis in epileptic foci induced by mechanical or chemical injury. More interestingly, it differs from the stereotyped pattern of gliosis observed in the hippocampus following injection of several convulsants in experimental animals ${ }^{15}$ and in humans suffering from partial seizures with complex symptomatology. ${ }^{16}$ There appears to be a consistent association of gliosis with some type of seizures, but not with others, presumably reflecting different pathophysiological mechanisms.

The pathological basis of the primary generalized epilepsies in humans has not been fully elucidated. Although these epilepsies are usually considered not associated with demonstrable histological lesions, and some reports support this contention, 23 others describe cortical microdysgenesis without gliosis, ${ }^{24}$ and one patient with "impulsive petit mal and grand mal" on awakening demonstrated extensive gliosis in the cerebellar cortex, nucleus dentatus and nucleus ruber. ${ }^{25}$ Given the differences in clinical manifestations, age of onset, and response to therapy of different syndromes of human primary generalized epilepsy, it is unlikely that a common pathology and pathophysiology underlies all of them. It has been proposed, on the basis of experimental and clinical evidence, that loss of restraining influences originating from the upper brainstem tegmentum secondary to a variety of causes, is responsible for the development of cortical bilateral synchronous spike-wave discharge. ${ }^{26}$ In this respect, it is interesting to note that although the avian telencephalon is organised on a basal nuclear basis, rather than on a cortical laminar basis as in mammals, the brainstem and cere- 
bellum are very similar in both classes of vertebrates. ${ }^{27}$ The remarkable similarity in seizure pattern, nature of the eliciting stimulus, and response to therapy between epileptic fowl and humans with photosensitive epilepsy in spite of the divergent organisation of the telencephalon suggests that further study of this mutant may clarify unresolved issues in human primary generalized epilepsy.

\section{ACKNOWLEDGEMENTS}

We thank Mrs. L. Kobylinski for excellent technical help and Mrs. M. Hopewell for typing the manuscript. Maintenance of the Epileptic flock is supported by the MRC of Canada, MA-8604. The study was supported by grants from the Saskatchewan Health Research Board, and the College of Medicine of the University of Saskatchewan.

\section{REFERENCES}

1. Anderson VE, Hauser WA, Rich SS. Genetic heterogeneity in the epilepsies. In: Delgado-Escueta AV, Ward AA, Woodbury DM, Porter RJ, eds. Basic Mechanisms of the Epilepsies. Molecular and Cellular Approaches. Advances in Neurology. Raven Press, New York 1986: 59-75.

2. Delgado-Escueta AV, White R, Greenberg DA, et al. Looking for epilepsy genes: Clinical and molecular genetic studies. In: Delgado-Escueta AV, Ward AA, Woodbury DM, Porter RJ, eds. Basic Mechanisms of the Epilepsies. Molecular and Cellular Approaches. Advances in Neurology, vol. 44. Raven Press, New York 1986: 77-95.

3. Paul LA, Fried I, Watanabe K, et al. Structural correlates of seizure behavior in the mongolian gerbil. Science 1981; 213:924-926.

4. Ribak CE. Contemporary methods in neurocytology and their application to the study of epilepsy. In: Delgado-Escueta AV, Ward AA, Woodbury DM, Porter RJ, eds. Basic Mechanisms of the Epilepsies. Molecular and Cellular Approaches. Advances in Neurology, vol. 44. Raven Press, New York 1986: 739-764.

5. Crawford RD. Epileptiform seizures in domestic fowl. J Hered 1970; 61: 185-188.

6. Crichlow EC, Crawford RD. Epileptiform seizures in domestic fowl II. Intermittent light stimulation and the electroencephalogram. Can J Physiol Pharmacol 1974; 52: 424-429.

7. Johnson DD, Davis HL, Crawford RD. Pharmacological and biochemical studies in epileptic fowl. Federation Proc 1979; 38: 2417-2423.

8. Johnson DD, Crawford KDA, Crawford RD. Febrile seizures in epileptic chicks: The effects of phenobarbital, phenytoin and valproate. Can J Neurol Sci 1983; 10: 96-99.

9. Johnson DD, Davis HL. Drug responses and brain biochemistry of the Epi mutant chicken. In: Ookawa $\mathrm{T}$, ed. The Brain and Behaviour of the Fowl. Jpn Sci Soc Press, Tokyo 1983: 281-296.

10. Bignami $A$, Dahl $D$. The astroglial response to stabbing.
Immunofluorescence studies with antibodies to astrocytic specific protein (GFA) in mammalian and submammalian vertebrates. Neuropathol Appl Neurobiol 1976; 2: 99-110.

11. Trachtenberg MC, Pollen DA. Neuroglia: Biophysical properties and physiological function. Science 1970; 167: 1248-1252.

12. Brotchi J, Tanaka T, Leviel V. Lack of activated astrocytes in the kindling phenomenon. Exp Neurol 1978; 58: 119-125.

13. Grisar TM. Neuron-glia relationships in human and experimental epilepsy: A biochemical point of view. In: Delgado-Escueta AV, Ward AA, Woodbury DM, Porter RJ, eds. Basic Mechanisms of the Epilepsies. Molecular and Cellular Approaches. Advances in Neurology, vol. 44. Raven Press, New York. 1986: 1045-1073.

14. White HS, Woodbury DM, Chen CF, et al. Role of glial cation and anion transport mechanisms in the etiology and arrest of seizures. In: Delgado-Escueta AV, Ward AA, Woodbury DM. Porter RJ, eds. Basic Mechanisms of the Epilepsies. Molecular and Cellular Approaches. Advances In Neurology, vol. 44. Raven Press, New York 1986: 695-712.

15. Olney JW, Collins RC, Sloviter RS. Excitotoxic mechanisms of brain damage. In: Delgado-Escueta AV, Ward AA, Woodbury DM, Porter RJ, eds. Basic Mechanisms of the Epilepsies. Molecular and Cellular Approaches. Advances in Neurology, vol. 44. Raven Press, New York 1986: 857-877.

16. Meldrum BS, Corsellis JAN. Epilepsy. In: Adams JH Corsellis JAN Duchen LW, eds. Greenfield's Neuropathology. Wiley, New York 1984: 921-950.

17. Green JR, Scheetz DG. Surgery of epileptogenic lesions of the temporal lobe. Arch Neurol 1964; 10: 135-148.

18. Dam AM, Bajorek JC, Lomax P. Hippocampal neuron density and seizures in the Mongolian gerbil. Epilepsia 1981; 22: 667-674.

19. Sturkie PD. Avian Physiology, 3rd ed. Springer-Verlag, New York 1976.

20. Jungherr EL. The neuroanatomy of the domestic fowl (Gallus domesticus). American Association of Avian Pathologists, Amherst, Mass. 1969.

21. van Tienhoven A, Juhasz LP. The chicken telencephalon, diencephalon and mesencephalon in stereotaxic coordinates. J Comp Neurol 1962; 118: 185-197.

22. Munoz-Garcia D, Ludwin SK. Gliogenesis in organotypic tissue culture of the spinal cord of the embryonic mouse. I. Immunocytochemical and ultrastructural studies. J Neurocytol 1986; 15: 173-290.

23. Cohn R. A neuropathological study of a case of petit mal epilepsy. Electroenceph Clin Neurophysiol 1968; 24: 281.

24. Meencke H-J, Janz D. Neuropathological findings in primary generalized epilepsy: A study of eight cases. Epilepsia 1984; 25: 821.

25. Janz D, Neimanis G. Clinico-anatomical study of a case of idiopathic epilepsy with impulsive petit mal ("Impulsiv-Petis mal") and Grand Mal on awakening ("Aufwach-Grand mal"). Epilepsia 1961; 2: 251-269.

26. Stevens JR. Focal abnormality in petit mal epilepsy. Neurology 1970; 20: 1069-1076.

27. Sarnat HB, Netsky MG. Evolution of the Nervous System, 2nd Ed. New York, Oxford Press 1981. 